\title{
Glacier mass balance studies in the swiss Alps
}

\author{
M. Aellen \\ Laboratory of Hydraulics, Hydrology and Glaciology Federal Institute of Technology in Zurich
}

\begin{abstract}
In the Swiss Alps, glacier mass balance studies are going on since 1882, when a stake network was installed on Rhonegletscher, where annual (in some years also seasonal) ablation and accumulation measurements went on until 1922 [1-3]. In recent studies, annual mass balances of Rhonegletscher were established for the period 1882 to 1987, either computed from a stake network observed from 1978 to 1982, reconstructed from the observations on the former stake network or calculated from climatic data observed at the meteorological stations of Andermatt and Reckingern [4-6].

Meanwhile, stakes were planted on other glaciers to determine annual and seasonal firn accumulation. In some cases, these long-term projects serving mainly scientific interests are still going on, namely on Claridenfin since 1914, on Silvrettagletscher since 1915 and on Jungfraufirn since 1918 [7-9].
\end{abstract}

A practical need giving opportunities for numerous mass balance studies on various glaciers arouse with the planning of water storage basins for hydroelectric power plants in the High Alps [10-12]. In most cases, these studies were short-termed. In other cases, they lead to the continuous ongoing records which are based on various methods. On Unteraar- and Oberaargletscher, annual variations of ice volume and ice thickness are determined in the ablation area by the use of geodetic methods since 1924 and 1946 respectively [13-15]. On Limmern-, Plattalva-, Silvrettaand Griesgletscher, annual mass balances are established by the use of glaciological methods since 1947, 1959 and 1961, when the respective stake networks were installed [16-21]. For the Aletsch glaciers, an average net balance is derived from a hydrological model calculating daily to annual variations of water storage in the Massa river basin since 1922 [22-24]. Further mass balance records may be computed from stake networks observed on the glaciers of the Mattmark region since 1945 and on glacier de Giétro since $1966[25,26]$.

As a control of the annual mass balances, variations of total volume, surface area and mean thickness were determined by the use of geodetic methods (based on aerial photogrammetry since 1946) for pluri- or multiannual periods [27-29]. An annual check is given in the case of Griesgletscher by the hydrological balances established for the catchment area of the power plants storage basin and in the case of the Aletsch glaciers by the average net balances computed from a stake network observed on Grosser Aletschgletscher from 1950 to $1986[18,24]$.

The particular records are continuous over rather short periods only (from less than 4 up to 8 decades). Hence, in attempts to complete some of these records for a secular period by the use of various methods for calculating annual mass balances, continuous records were reconstructed for Rhonegletscher from 1882 to 1987, for the Aletsch glaciers from 1900 to 1993 and for Limmern- and Plattalvagletscher from 1914 to 1984 [6]. Others may be reconstructed by the use of a continuity model from ice thickness and flow velocity variations measured on stone lines, where the total ice depth is known from seismic or radar soundings [30, 31]. Annual observations on stone lines lasted from 1874 to 1922 on Rhonegletscher and from 1924 to 1969 on Unteraargletscher $[1-3,13]$. While on the latter they were replaced by aerial photogrammetric surveying, they are going on since 1967 on glacier de Corbassière [26].

As main results, a comparison of the observed annual records (fig. 5) indicates a clear although variable general tendency of vanishing glacier mass in all regions of the Swiss Alps, whereas a comparison of the same records with

\section{Etudes de bilans de masse d'un glacier dans les Alpes suisses}

En 1882, un réseau de balises d'accumulation et d'ablation a été installé sur le glacier du Rhône. Depuis lors, l'étude des bilans de masse glaciaires dans les Alpes suisses a été continuellement poursuivie d'une manière ou d'une autre sur l'un ou l'autre d'une bonne douzaine de glaciers, soit pour des buts scientifiques de recherches fondamentales, soit pour des buts pratiques surtout à la demande des aménagements hydroélectriques en haute montagne. Cependant, les séries d'observation particulières ne portent que sur une période de 2 à 8 décennies. A l'aide de méthodes statistiques utilisant des données météorologiques et hydrologiques comme variables indépendantes, ces séries de bilans de masse annuels ont été complétées de manière à avoir des séries continues portant sur des périodes quasi-séculaires. 
reconstructed ones and with results of pluriannual geodetic surveys (fig. 6) indicates a strong variability of vanishing velocities over all regions and equally so within a local river basin.

\section{I $\square$ OBSERVATION NETWORKS AND MASS BALANCE RECORDS}

The observation networks in use for the annual surveys on glacier variations in the Swiss Alps are described in glaciological publications and also in the Hydrological Atlas of Switzerland, the latter giving a location map and a list of all network glaciers [12, 32-34]. The list contains informations on morphological parameters, measurement techniques, methods of determination, length of records and refers to sponsoring agencies. Extracted from that list is the table in this paper (tabl. l) which mainly refers to the records presented in the graphs (fig. 1-6) and to the publications consulted as data sources. For Aletsch-, Gries-, Limmern-, Plattava- and Silvrettagletscher, the results of the annual measurements and the results of the pluriannual geodetic surveys are published regularly in the national and in the international reports on fluctuations of glaciers $[9,29,36,37]$.

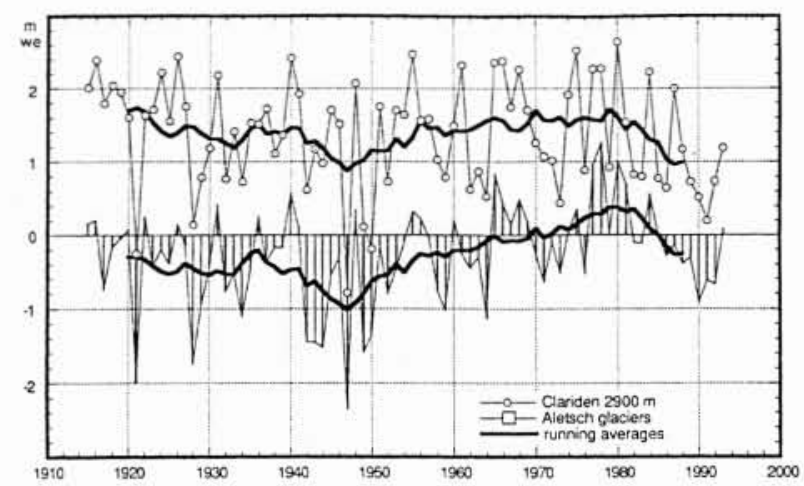

1. Annual mass variations $1914-1993$ : firn accumulation on Clarifenfirn (stake at $2900 \mathrm{~m}$ alt.) and average net balance of Aletsch glaciers (hydrologic model Massa river basin, $195 \mathrm{~km}^{2}$ ) with running averages (over 11 years). Correlation coefficient $r=0.80$.

\section{II $\square$ METHODS OF DETERMINATION AND MEASUREMENT TECHNIQUES}

As it is shown in table 1 , glacier mass balances are established by various methods from various data samples collected by various measurement techniques. This holds also for the data samples collected either in the accumulation area or in the ablation area alone. These samples might eventually serve as a base to compute further net balance records or to reconstruct missing years of incomplete records (or intermittant ones based on geodetic surveys) as it has been done e.g. for the records of Limmernand Plattalvagletscher, when they were extrapolated backwards from 1947 to 1914 , based on the annual firn accumulation rates determined on Claridenfirn [6]. Detailed informations on measurement techniques and determina-

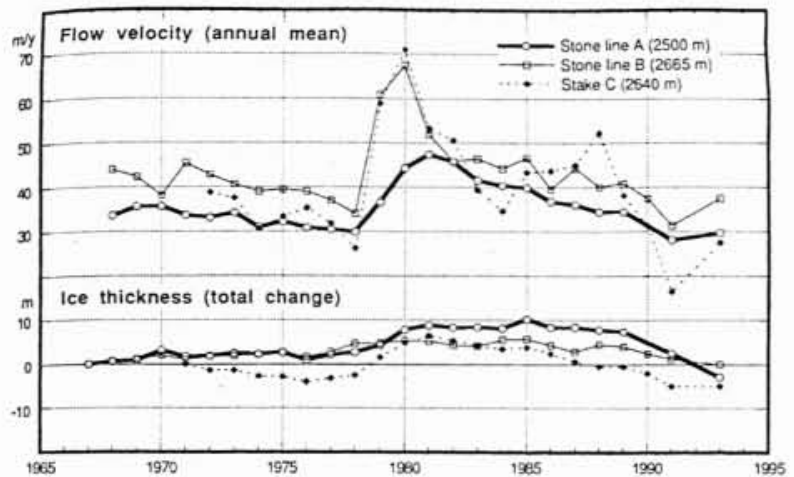

2. Glacier de Corbassière 1967-1993 : annual variations of surface velocity and ice thickness observed on two stone lines and on an intermediate stake.



3. Glacier de Corbassière 1967-1991 : components of annual mass balances computed from the measurements on the stone lines.

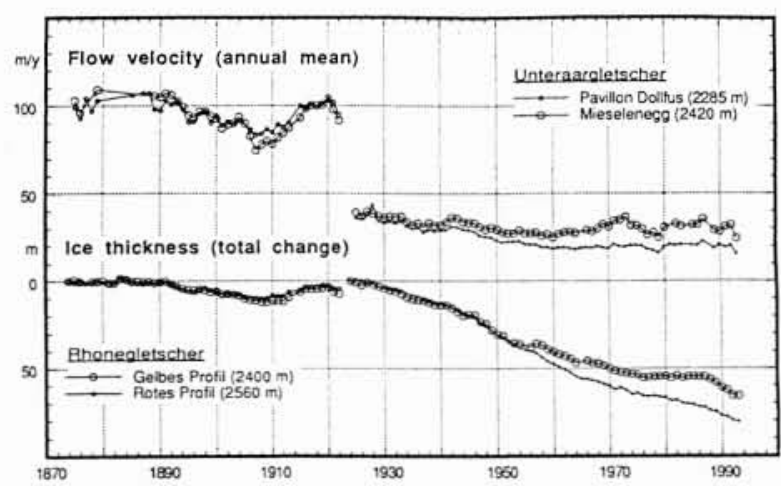

4. Rhonegletscher 1874-1922 and Unteraargletscher 1924-1992 : annual variations of surface velocity and ice thickness observed on stone lines.

tion methods are given in most papers referred to as data sources in table 1. The records represented in this papers graphs give either an overview over the main results of long-term observations (fig. $I, 5,6$ ) or may indicate some possibilities to complete these records by extracting supplementary informations on mass balance from existing data sets (fig. 2-4) which in this respect have been scarcely or poorly exploited so far $[31,38]$. From the records of 


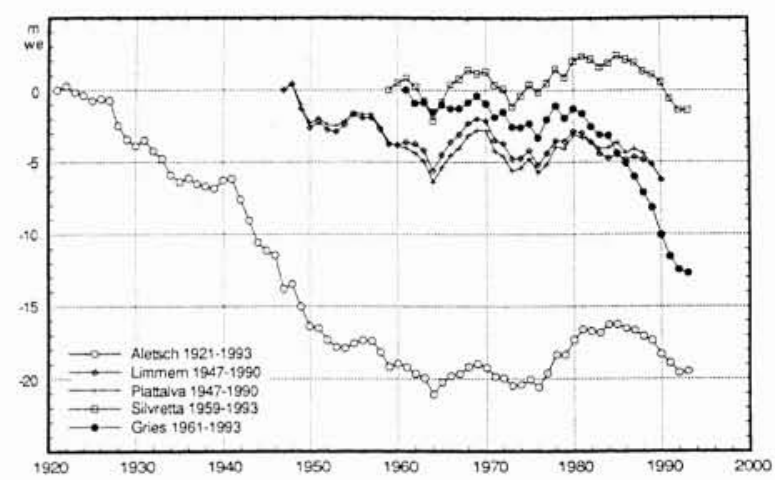

5. Glacier mass balances in the Swiss Alps : cumulated values of ongoing annual records.

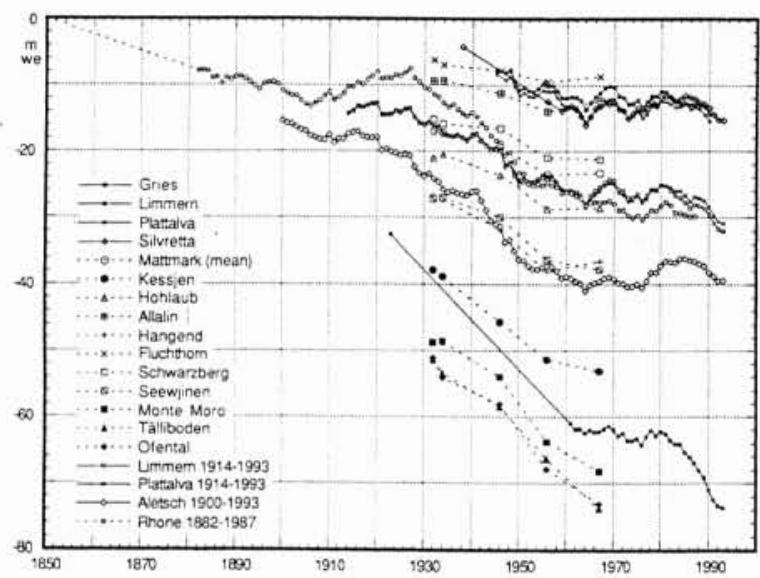

6. Glacier mass balances in the Swiss Alps : cumulated values of ongoing and reconstructed annual records compared to pluriannual geodetic records of the Mattmark glaciers.
Table 1. - Glacier mass balance records. a) Annual observations

\begin{tabular}{|c|c|c|}
\hline Glaciers & Period & References \\
\hline \multicolumn{3}{|c|}{$\begin{array}{l}\text { Average net balances computed by direct methods } \\
\text { based on glaciologic data (stake networks, snow } \\
\text { pits) }\end{array}$} \\
\hline Rhône & $\begin{array}{l}1884-1909 \\
1979-1982\end{array}$ & $\begin{array}{l}\text { [5] } \\
{[4]}\end{array}$ \\
\hline va & & {$[16,2$} \\
\hline & & \\
\hline & & \\
\hline & & {$[18$,} \\
\hline Gietro & 1966- & [26 \\
\hline \multicolumn{3}{|c|}{$\begin{array}{l}\text { indirect methods based on climatic, hydrologic or gla- } \\
\text { ciologic data (regression models) }\end{array}$} \\
\hline ône & $1882-1987$ & {$[5,6]$} \\
\hline & & \\
\hline & & {$[6,10,22,23,24]$} \\
\hline Limm & 1914-1984 & [6] \\
\hline \multicolumn{3}{|c|}{$\begin{array}{l}\text { Accumulation rates point measurements (stakes, } \\
\text { snow pits) }\end{array}$} \\
\hline & $1883-1922$ & {$[1,2$} \\
\hline & & {$[7,8$} \\
\hline & & {$[7$,} \\
\hline 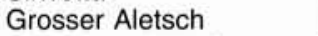 & 191 & {$[7$,} \\
\hline \multirow{2}{*}{\multicolumn{3}{|c|}{$\begin{array}{l}\text { Ablation ratespoint measurements (stakes, stake } \\
\text { networks }\end{array}$}} \\
\hline & & \\
\hline & & \\
\hline-1 & & \\
\hline & & \\
\hline- Allanil & & \\
\hline \multirow{2}{*}{\multicolumn{3}{|c|}{ profile measurements (stone lines, }} \\
\hline & $1874-1922$ & {$[1,2,0,00]$} \\
\hline & & {$[13,14,15,31,35]$} \\
\hline & & [13] \\
\hline & & \\
\hline
\end{tabular}

b) Pluriannual observations (topographic surveys)

\begin{tabular}{|l|c|c|c|c|}
\hline Glaciers & Terrestrial surveys & Aerial surveys & Digital models & References \\
\hline \multicolumn{2}{|c|}{ Change of area, volume and ice thickness (geodetic methods) } & & \\
Rhône & 1874 & $1959 / 1969$ & $15]$ \\
Gries (Ägina) & 1923 & 1961,1979 & 1986,1991 & {$[18,19,20,29]$} \\
Grosser Aletsch & $1926 / 27$ & 1947,1957 & & {$[29]$} \\
Aletsch glaciers & $1926 / 27$ & 1957 & 1991 & (unpubl.) \\
Basodino & 1929 & $1949,1971,1979$ & {$[17,29]$} \\
Silvretta & 1938 & $1956,1959,1973$ & & {$[25,27,29]$} \\
Mattmark glaciers & 1932,1934 & $1946,1956,1967$ & & {$[16,29]$} \\
Limmern, Plattalva & 1945 & $1947,1959,1977$ & & {$[167$} \\
\hline
\end{tabular}

stone line surveying e.g., annual variations of ablation at different altitude levels may be reconstructed for a 120 years period by the mean of the continuity model.

The methods of determination have periodically been adapted according to major changes in the number of stakes observed on a particular glacier. Hence, revised versions have been published for the mass balance records based on direct glaciological observations (tabl. la). The different methods of determination and their results are discussed in the respective case studies [16-21]. The latest versions of the results are summed up in figure 5.

The mass balance records established by indirect methods (tabl. la) were calculated by means of linear regressions from climatic data (PT-models based on annual precipitation and average summer air temperature), hydrologic data (PR-model based on specific precipitation and runoff in a river basin) or glaciologic data (regression model based on firn accumulation). Detailed information on the recently revised models used to compute or partially reconstruct these records is given in [6]. The latest versions of the results are summed up in figure 6.

In spite of the wide spreading in measurement techniques and determination methods, resulting records may well correlate with each other even in cases as different as a point measurement at a single site and a global model for a river basin. A sample is given in figure 1, where firn accumulation rates observed at a single site on Claridenfirn (Glaronese Alps) are compared to average net balances 
determined for the Aletsch glaciers (Bernese Alps), a group of 33 very small to very large glaciers (surface range : $0.03-86.7 \mathrm{~km}^{2}$, altitude range : $1550-4195 \mathrm{~m}$ ) covering about $2 / 3$ of the Massa river basins surface area $\left(195 \mathrm{~km}^{2}\right)$.

For most glaciers whose annual net balance is recorded, mass change has been determined for pluri-annual periods also by the use of geodetic methods $(t a b l . ~ I b)$. The results were taken into account for the extrapolation of the annual records. These are compared in figure 6 to reconstructed records and to the results of the geodetic surveys on the glaciers in the Mattmark region (Valais Alps), a group of 10 glaciers (surface range : $0.23-9.6 \mathrm{~km}^{2}$, altitude range : $2320-4190 \mathrm{~m}$ ) covering roughly $2 / 5$ of a $65 \mathrm{~km}^{2}$ surface area the head of the Vispa river basin. The reconstructed records are reliable as far as they are interpolated. The extrapolation further backward to 1850 according to their general tendency is purely fictive and has been used merely as a trick to spread out the fan of curves, aiming at a better overview in a summarizing compilation of nearly all available records.

The continuity model is applied to establish an annual mass balance for the partial areas below two stone lines observed in the ablation area of glacier de Corbassière (Valais Alps). The basic data, namely mean annual surface velocity and ice thickness variations, are shown in figure 2 . The balance components, namely computed vertical velocity (emergency), observed variation of ice thickness (or surface level) and resultant mass change (ablation), are represented in figure 3. A comparison with ablation rates determined on a nearby stake network on glacier de Giétro gave proof of a fair reliability for the model. In fact, this holds for all years except 1979, when the ice movement accelerated in such a manner (in the order of $75 \%$ in the higher parts of the glaciers tongue) that the model produced a focal point in the ablation curves. The results are nevertheless encouraging to apply the model in other cases of stone line surveying such as the long-term surveys on Rhonegletscher (1874 to 1922) and on Unteraargletscher (since 1924) where in both cases several other stone lines were observed besides those referred to in figure 4 .

An important data source which might enable studies on glacier mass variations and climatic changes over a secular period in nearly all glacierized regions of the Swiss Alps is given by the numerous records on glacier length variations. Annual surveys on a particular network are going on since 1880 and the results have regularily been published in the reports on the behaviour of the terminal front of about 50 to 120 sampled glaciers [9, 35-37]. Various approches based on regression models relating length variations to climatic or to mass balance records were discussed in case studies [39-41] and systematic regional studies have been undertaken or are under way [42, 43].

\section{III 口 RESULTS}

The main results of mass balance studies in the Swiss Alps are summed up in figure 5 for the ongoing annual records. In figure 6, these records, completed with results of the geodetic surveys, are compared to reconstructed annual records and to the geodetic records of the glaciers in the Mattmark region. In a summarizing comment, we may point out the following statements :

- A general tendency to glacier mass loss is more or less obvious from all records ; more so in the southern, less so in the northern regions of the Swiss Alps.
- Periods of mass gain interrupting the long term tendency in the years around 1890, 1920 and 1980 turned out to be merely episodic.

- A strong variability of mass loss seems to be a typical feature at any scale, at a large scale for different regions of the Alps, but equally so at a local scale for different glaciers within a river basin. It probably depends mainly on orographic conditions controlling the precipitation regime.

\section{Acknowledgements}

First of all, I have to thank a distinct number of persons in the chair of this symposium for inviting me to give this review on mass balance studies in Switzerland. Most of all, I have to thank an uncounted number of persons for contributing year per year - in several cases during almost a life time to these studies at any level from field work for the initial data acquisition to editors work on the final reports. Last but not least, I have to thank an unknown number of persons involved as a representative of the sponsoring agencies for supporting these again and again on any field from the logistic and financial to the administrative and scientific domains.

\section{Références}

[1] Mercanton P.L. (1916). - Mensurations au glacier du Rhône 1874-1915. Nouveaux mémoires de la Société helvétique des sciences naturelles, vol. $52,189 \mathrm{p}$. (avec portefeuille de 10 plans).

[2] L + T (Eidgenössische Landestopographie) (1916-1917). Jährlicher Bericht über die Vermessung des Rhonegletschers. Archiv der Gletscherkommission (unveröffentlicht).

[3] LÖTSCHG O. (1918-1922). - Jährlicher Bericht über die Vermessung des Rhonegletschers. Archiv der Gletscherkommission (unveröffentlicht).

[4] FUNK M. (1985). - Räumliche Verteilung der Massenbilanz auf dem Rhonegletscher und ihre Beziehung zu Klimaelementen. Zürcher Geographische Schriften, H. 24, Geographisches Institut ETH Zürich, $183 \mathrm{~S}$.

[5] CHEN J. \& Funk M. (1990). - Mass balance of Rhonegletscher during 1882/83-1986/87. Journal of Glaciology, vol. 36 , no. $123,199-209$.

[6] Múller H., Funk M., Aellen M., Kappenberger G. (1995) (in press). - Langjährige Massenbilanzreihen von Gletschern in der Schweiz. Zeitschrift für Gletscherkunde und Glazialgeologie.

[7] FIRNBERICHTE (1914-1978), - Der Firnzuwachs pro... in einigen schweizerischen Firngebieten. Ber. $\mathrm{Nr} .1$ (1913/14)-7 (1919/20) in Jahrbuch Ski, 9.-15.Jg., Nr. 8 (1920/21)-64 (1976/77) in Vierteljahrsschr. der Naturf. Gesellschaft Zürich, 67.-123.Jg. ; ab 1978 gekürzt im 99./100.111./112. Gletscherbericht, Jahrbuch der Gletscherkommission 1977/78-1990/91, Kap. 5.5.

[8] MÓller H. \& Kappenberger G. (1991). - ClaridenfirnMessungen 1914-1984. Zürcher Geographische Schriften, H. 40, Geographisches Institut ETH Zürich, $79 \mathrm{~S}$.

[9] Rapports glaciologiques 1881-1994. Les glaciers des Alpes suisses en.... Rapports $n^{\circ} 1$ (1880) et 2 (1881) dans Echo des Alpes, Genève, $17^{\circ}-18^{\circ}$ ann. : $n^{\circ} 33$ (1882)-44 (1923) dans Annuaire du CAS, Berne, $18^{\mathrm{c}}-58^{\mathrm{e}}$ ann. : $\mathrm{n}^{\mathrm{os}} 45$ (1924)-114 (1992/93) dans revue Les Alpes, $1^{\mathrm{re}}-70^{\mathrm{c}}$ ann. ( $\mathrm{n}^{\mathrm{os}} 95-114 \mathrm{en}$ extrait) : $\mathrm{n}^{\circ \mathrm{s}}$ 95/96-111/112 (vol. doubles complétées) dans Annuaire de la Commission des glaciers, VAW/EPF Zurich.

[10] KASSER P. (1959), - Der Einfluss von Gletscherrïckgang und Gletschervorstoss auf den Wasserhaushalt. Wasser- und Energiewirtschaft, 51.Jg., Nr.6, 155-168. 
[11] BEZINGE A. and KASSER P. (1981). - Glaciers and electric power production. Switzerland and her glaciers (Kasser P. \& Haeberli W. ed.), Swiss national tourist office ZürichKümmerly + Frey, Geographical Publishers Berne, 166-183.

[12] KASSER P. (1981). - Rezente Gletscherveränderungen in den Schweizer Alpen. Gletscher und Klima. Jahrbuch 1978 der Schweizerischen Naturforschenden Gesellschaft, wiss. Teil, 106-138.

[13] Flotron A. (1924-1993). - Vermessung der Aaregletscher: Jährlicher Bericht an Kraftwerke Oberhasli, Archiv der Gletscherkommission (unveröffentlicht).

[14] HAEFElI R. (1970). - Changes in the behaviour of the Unteraargletscher in the last 125 years. Journal of Glaciology, vol. 9, nr. 56, 195-212.

[15] FunK M. and RöTHLISBERGER H. (1989). - Forecasting the effects of a planned reservoir that will partially flood the tongue of Unteraargletscher. Annals of Glaciology 13, 7681.

[16] SiegenthaleR H. (1983). - Limmern- und Plattalvagletscher. Die Gletscher der Schweizer Alpen 1975/761976/77.97.198. Bericht, Jahrbuch der Gletscherkommission, 185-201.

[17] Kasser P., Aellen M. \& Siegenthaler H. (1982). Silvrettagletscher. Die Gletscher der Schweizer Alpen 1973/74-1974/75.95./96. Bericht, Jahrbuch der Gletscherkommission, 146-157.

[18] Siegenthaler H. (1986). GriesGletsCher (Wallis). - Die Gletscher der Schweizer Alpen 1977/78-1978/79.99./100. Bericht, Jahrbuch der Gletscherkommission (Jubiläumsband), 153-177.

[19] Aellen M. und FUNK M. (1988). - Massenbilanz des Griesgletschers von 1961 bis 1986. Vergleich verschiedener Bestimmungsverfahren. Festschrift Hans Röthlisberer, Mitt. VAW Nr. 94, ETH Zürich, 9-50.

[20] Funk M., Morelli R. and Stahel W. (in press), - Mass balance of Griesgletscher 1961-1984: different methods of determination. Zeitschrift für Gletscherkunder und Glazialgeologie.

[21] Funk M., StAhel. W. et MORElli R. (en préparation). Une analyse statistique multivariate des bilans de masse annuels des glaciers Gries, Silvretta, Limmern et Plattalva.

[22] HAEFELI R. und KASSER P. (1948), - Beobachtungen im Firn- und Ablationsgebiet des Grossen Aletschgletschers. Schweizerische Bauzeitung, 66.Jg., Nr.35, 477-481, Nr.36, 489-494.

[23] KASSER P. (1954). - Sur le bilan hydrologique des bassin. glaciaires avec application au Grand Glacier d'Aletsch. IAHS Publication no. 39, 331-350.

[24] AELLEN M. et FUNK M. (1990). - Bilan hydrologique du bassin versant de la Massa et bilan de masse des glaciers d'Aletsch (Alpes bernoises, Suisse). IAHS Publication no. 193, 89-98.

[25] KASSER P. (1972). - Messungen an den Gletschern des Mattmarkgebiets. Die Gletscher der Schweizer Alpen 1969. 1970.91. Bericht, Publikation der Gletscherkommission SNG, 53-60.

[26] Aellen M. (1993). Les Glaciers du Haut Val de Bagnes. Excursion de la $173^{\mathrm{c}}$ Assemblée de l'AASN (Verbier), documentation glaciologique, 14 p. (non publiée).

[27] Lôtschg O. (1944). - Die Bedeutung und Bewertung der Vorratsänderungen im Wasserhaushalt der Gletscher in Schweizer Hochgebirge. Zum Wasserhaushalt des Schweizer Hochgebirges 1.Bd, 1.Teil, 2.Abt., Kap. 4, 61-74.
[28] KASSER P. (1960). - Glaziologischer Kommentar zur neuen im Herbst 1957 aufgenommenen Karte 1 :10'000 des Grossen Aletschgletschers. AIHS Publication no. 54 (Helsinki), 216-223.

[29] KASSER P. (1967). - Fluctuations of Glaciers 1959-1965 (Vol. I, Pilot Study). A contribution to the International Hydrological Decade. IASH (ICSI)-UNESCO.

[30] SCHRAM K. (1966). - Untersuchung der vertikalen Komponente der Gletscherbewegung und der Deformation des Eises im Zungengebiet des Hintereisferners. Ber. Nat.-Med. Verein Innsbruck, Bd. 54, 75-150.

[31] REYNAud L., VAllon M. and Letréguilly A. (1986), Mass balance measurements: problems and two new methods of determining variations. Journal of Glaciology vol. 32 , no. 112 , 446-454.

[32] KASSER P. et Aellen M. (1976). - Les variations des glaciers suisses en 1974/75 et quelques indications sur les résultats récoltés pendant la Décennie Hydrologique Internationale de 1964/65 à 1973/74. La Houille Blanche no. 6/7. 467-481.

[33] AEl.len M. (1986). - Das Beobachtungsnetz der Gletscherkommission. Hundert Jahre Schweizer Gletscherberichte. 99./100.Bericht, Jahrbuch 1977/78-1978/79 (Jubiläumsband), 239-259.

[34] Hydrological Atlas of Switzerland 1992. Sheet 3.1: Snow cover and glacier gauging networks. Swiss national hydrological and geological survey Berne.

[35] AELlEN M. (1986a). - Jährliche Längenänderung der Gletscher von $1879 / 80$ bis $1978 / 79$. Hundert Jahre Schweizer Gletscherberichte. 99./100.Bericht, Jahrbuch 1977/78-1978/79 (Jubiläumsband), 260-276.

[36] IAHS (ICSI)-UNESCO (1967-1985). Fluctuations of Glaciers Vol. I (1959-1965), Vol. IV (1975-1980).

[37] IAHS (ICSI)-UNEP-UNESCO (1988, 1993). Fluctuations of Glaciers, Vol. V (1980-1985), Vol. VI (1985-1990).

[38] AELLEN M. (1995). - Jährlich erfasste Gletscherveränderungen in den Schweizer Alpen. 100 Jahre Gletscherkommission. 100'000 Jahre Gletschergeschichte. Festschrift 173. Jahresversammlung der SANW in Verbier (im Druck).

[39] RENAUd A. (1963). - Analyse climatique des variations de longueur des glaciers de Pizol et Sardona (Suisse). Bull. Soc. vaudoise des Sciences naturelles no. 310, vol. 68 , fasc. $5,195-204$.

[40] MÖller P. (1988). - Parametrisierung der GletscherKlima-Beziehung für die Praxis : Grundlagen und Beispiele. Diss. ETH, Mitteilunger der VAW Nr.95, ETH Zürich, $228 \mathrm{~S}$.

[41] HuLOT L. (1993). - La signification climatique des variations de longueur des glaciers alpins. Mémoire de DEA, Mécanique des Milieux Géophysiques et Environnement, Université J. Fourier de Grenoble I, 40 p.

[42] MAISCH M. (1992). - Die Gletscher Graubündens. Rekonstruktion und Auswertung der Gletscher und deren Veränderungen seit dem Hochstand von 1850 im Gebiet der östlichen Schweizer Alpen (Bündnerland und angrenzende Regionen). Teil A : Grundlagen-Analysen-Ergebnisse, Teil $B$ : Verzeichnisse-Daten-kataloge-Gletscherkarten. Geographisches Institut Universität Zürich, $324+128 \mathrm{~S}$.

[43] Hoelzle M. (1994). - Permafrost und Gletscher im Oberengadin. Grundlagen und Anwendungsbeispiele für automatisierte Schätzverfahren. Diss. ETH, Mitteilungen der VAW Nr.132, ETH Zürich, $121 \mathrm{~S}$. 